\title{
A study on the application prospect of functional shirt fabrics in the uniform industry
}

\author{
Xing Xue ${ }^{1}$, Gu Wen ${ }^{2}$, Li Li ${ }^{1}$, Liu Xiaogang ${ }^{2}$ \\ ${ }^{1}$ Donghua University, NO.1882 West Yanan Road, Shanghai, 20051, China \\ ${ }^{2}$ Donghua University, Shanghai Fashion Design \& Value Creation Collaborative Innovation Center, NO.1882 West Yanan Road, Shanghai, \\ 20051, China.
}

\begin{abstract}
This paper analyses the value of functional shirt fabrics in the application of uniform industry. Through the functional research of the professional wear shirt fabric, we analyzed the industry needs and demands strength, and on the basis of the analysis above, we combed the industry forefront research, and then we put forward two development directions of functional shirt fabrics to provide some suggestions for the development of uniform shirt fabric.
\end{abstract}

\section{Introduction}

Uniform has the characteristic of strong wearing. Since shirt is a common category in uniform industry, the material is an important program which needs to research. In recent years, functional fabric is too numerous to mention, but there are still some blind spots in how to use them in uniform industry. This paper analysed the value of functional fabric applications, through the investigation of shirt fabric functional requirements to get a direction of research.

\section{The value of functional shirt fabrics in uniform industry}

\subsection{Social values}

The main values of companies in 21th century consider that the value of a company is not to pursuit of the interests maximize, but to realize value maximization. That means companies should create wealth effectively for community. [1] Dr. Manuela Weber of the University of Lüneburg described the CSV as a component of CSR benefits (CSR value appreciation), stakeholder relations (KPI), and sustainable development strategy elements for corporate social responsibility. Based on this theory, domestic scholars constructed the social value system of the enterprise, they pointed out that the content of the CSV should be the responsibility performance of the enterprise to the stakeholders, which can be divided into market contribution value, environmental contribution value and social contribution value. [3] Therefore, social value and social responsibility are inseparable to enterprises. To fabric enterprises, new functional shirt fabrics are not only to meet the needs of market consumers, and some environmental fabrics also can save environmental resources, pollution reduction and emission reduction, which can realize the value of the enterprise's environmental contribution at the same time. In recent years, with the concept of environmental protection clothing fabrics heated up, there are some important issues such as how to deal with the large numbers waste of uniforms, and how to use environmentally friendly recycled fiber, which can ensure the healthy development of uniform industry. These also can reflect enterprises' social responsibilities.

\subsection{Economic values}

Economic values of functional shirt fabric can reflect on both manufacturers and users. For the shirt fabric manufacturers, through technical means, uniform functional shirt fabrics give new blood for the market, and that improve the entire shirt fabric product system at the same time, which can provide more opportunities for the market. On the other hand, Scientific and technological innovation can be free from the vicious competition in price competition, making enterprises in a benign operation and construction. For the users, Highquality functional shirt fabric can increase the shirt life cycle, which can reduce unnecessary wear in the uniform cost. In addition, Functional fabrics help employees to improve work efficiency, promoting business operations thereby.

\subsection{Management values}

Under the conditions of socialist market economy, as the main body of economic activities, enterprises should not only pursue economic benefits, but also pursue the "moral character" of enterprise development and realize 
the moral management of enterprises. As Zhang Jun, a scholar of economics said that "An enterprise produces 'private goods', but its productivity is a 'public good'. But self-interest motive cannot guarantee the efficiency of enterprises; enterprises also need moral values, such as team spirit and corporate culture. Therefore, the moral plays a very important role." [4] The use of functional shirt fabric is a humanistic concern for workers actually, and it is a way to manage from the moral level, which can approach to help the workers to build loyalty to enterprise and promote the spiritual and cultural construction at the same time.

\subsection{Cultural values}

The core of enterprise culture is the enterprise values, and it is the terns made of values of things. Value is a relationship category, and human existence is the prerequisites, so it is meaningless analyzing enterprise value except human beings. Enterprise culture is comprehensively expressed with "corporate citizen"; itself is a "people-oriented" concept. [5] It is the enterprise which has "people-oriented" concept in itself that the functional shirt fabrics have adopted.

Edgar H Schein, a professor at MIT, built a corporate culture model, which is made of three levels. The surface is visible "behavior, rules, and some of the organization's typical products (artifacts)". The middle is the values advocated by the enterprise. The bottom is the basic assumptions of employees. Surface culture is the result of the underlying culture; and the reason why there will be visible surface of the cultural phenomenon is the underlying culture plays. [6] In terms of the functional fabric manufacturers, the persistence of new materials and environment-friendly technology can affect the employees' values, morality, behavior and way of thinking, affecting the institutional arrangement and evolution mechanism of enterprises. New functional materials' application is also an important way for enterprises to set up characteristic business model, characteristic products and promote good cultural values.

\section{Functional requirements of shirt fabrics for uniform industry}

Uniform shirt has a wide range of functional fabrics; the functional requirements of different industries must be different. With the high-tech in fabric research and development, Environmental protection, health care and other new functional fabrics have begun to emerge. But these new types of functional fabrics are still lack of understanding in uniform industry. Nowadays, the market demand is still based on basic functionality. Therefore, new functional shirt fabrics still have a large space for development in uniform industry.

\subsection{Research design}

In this research, Industry division is based on uniform shirt basic needs and style features divided into bank financial, government agencies, education and training, health care, hotel catering, entertainment, logistics, aviation, IT, advisory bodies, cultural media, road building Maintenance, real estate, department stores and other industries. This research is aimed at the working population. A total of 22 questions were designed to around with six directions. These are the basic information of the working population, the opinions on the existing shirt fabric, and the seasonal basic functional requirements of the shirt fabric, the demand for the new functional shirt fabric, acceptable price and uniform shirt dressing cycle. Through the questionnaire issued, the aim is to get the needs of market and understanding the needs of different sectors, key functional requirements, the new fabric prospects and R \& D direction.

\subsection{Questionnaire credibility}

A total of 223 valid questionnaires were collected from the survey. The Cronbach's Alpha coefficient is 0.944, and the Cronbach's Alpha coefficient is 0.945. Because the Alpha coefficient is greater than 0.8 , so the credibility of the questionnaire is satisfactory. The detail coefficient is shown as Table 1 and Table 2 .

Table 1. Case handling summary

\begin{tabular}{|c|c|c|c|}
\hline \multicolumn{2}{|c|}{} & $\mathrm{N}$ & $\%$ \\
\hline \multirow{3}{*}{ cases } & effective & 220 & 100.0 \\
\cline { 2 - 4 } & Excluded & 0 & .0 \\
\cline { 2 - 4 } & total & 220 & 100.0 \\
\hline
\end{tabular}

Table 2. Reliability statistics

\begin{tabular}{|c|c|c|}
\hline $\begin{array}{c}\text { Cronbach's } \\
\text { Alpha }\end{array}$ & $\begin{array}{c}\text { Based on standardized } \\
\text { items Cronbachs Alpha }\end{array}$ & $\begin{array}{c}\text { Number of } \\
\text { items }\end{array}$ \\
\hline .944 & .945 & 38 \\
\hline
\end{tabular}

\subsection{Result and discussion}

\subsubsection{Analysis on functional requirements of fabrics for uniform shirt}

(1) Analysis on basic functional requirements of uniform shirt

Basis functional requirements mean to meet the basic needs of wearing comfortable. According to the research result, most respondents dealt with the existing uniform shirt fabric satisfaction as the "general satisfaction" rating areas. There is an urgent need to improve the fabric permeability and wrinkle resistance, which demand more than $70 \%$, followed by wash ability, stain resistance, wear resistance; The key demand for functional fabrics in summer is permeability, cool feeling, followed by antipermeability; winter functional requirements focus on skin-friendly comfort, followed by anti-staic function. The detail propotion of basic functional requirements is shown as Figure 1 and Table 3.

(2) Analysis on new functional requirements of uniform shirt 
New functions as a non-essential function can improve the wearing feelings and working efficiency, which comes from care of employees. This article combined with the forefront of the industry, and listed functions such as the body skin care, plant health care, antibacterial immunity, safety reflection, intelligent temperature control, special luster, induction appearance, environmental regeneration, radiation protection, highstrength stretch, moisture-proof, cool touch, warm function 13 uniform shirt new fabric functions. Among them, the antibacterial immune, radiation protection moisture-proof, cool touch and warm function are higher than others, reaching $44.39 \%, 41.26 \%, 42.15 \%, 37.67 \%$ and $36.32 \%$ respectively. The detail propotion of new functional requirements is shown as Table 4 .

\subsubsection{Analysis on the difference of Industry demands}

According to the popularity of uniform shirts, the paper analyzes the eight industries of banking, government, education, entertainment, hotel catering, media, consultancy and shopping malls. The results of industry needs are as the table below (Table 5), which can help to develop the functional products for uniforms.

The Table 5 describes the core needs of shirt fabric functionality in the eight industries. There are commonalities and differences in the functional requirements for fabrics among industries. There are the common core needs of the industry such as anti-wrinkle, washability, permeability, skin-friendly, moisture-proof and cotton component. But according to the working environment and other social factors, there are differences in functional requirements of the fabric. The main difference among industries lies in the new function of preferences.

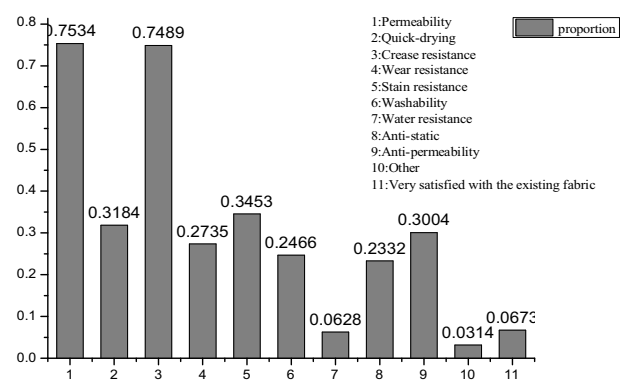

Figure 1. Existing uniform shirt fabric needs to be improved.

Table 3. Basic functional requirements of uniform shirt fabric

\begin{tabular}{|c|c|c|c|c|}
\hline functions & $\begin{array}{c}\text { Complete- } \\
\text { ly } \\
\text { unnecessar } \\
\text { y }\end{array}$ & $\begin{array}{c}\text { Unnecessa- } \\
\text { ry }\end{array}$ & $\begin{array}{c}\text { Necessa- } \\
\text { ry }\end{array}$ & $\begin{array}{c}\text { Very } \\
\text { necessa- } \\
\text { ry }\end{array}$ \\
\hline $\begin{array}{c}\text { Anti- } \\
\text { wrinkle }\end{array}$ & $6.73 \%$ & $5.83 \%$ & $25.56 \%$ & $61.88 \%$ \\
\hline Washable & $6.73 \%$ & $7.62 \%$ & $34.53 \%$ & $51.12 \%$ \\
\hline $\begin{array}{c}\text { Stain } \\
\text { resistance }\end{array}$ & $7.62 \%$ & $10.31 \%$ & $38.57 \%$ & $43.5 \%$ \\
\hline $\begin{array}{c}\text { Wear } \\
\text { resistance }\end{array}$ & $7.63 \%$ & $11.21 \%$ & $38.58 \%$ & $42.6 \%$ \\
\hline $\begin{array}{c}\text { Waterpro- } \\
\text { of }\end{array}$ & $18.39 \%$ & $28.25 \%$ & $32.74 \%$ & $20.63 \%$ \\
\hline
\end{tabular}

Table 4. New functional requirements of uniform shirt fabric

\begin{tabular}{|c|c|c|c|c|c|c|}
\hline New functions & $\begin{array}{c}\text { Completely } \\
\text { unnecessary }\end{array}$ & Unnecessary & $\begin{array}{c}\text { No } \\
\text { opinion }\end{array}$ & Necessary & $\begin{array}{c}\text { Very } \\
\text { necessary }\end{array}$ & $\begin{array}{c}\text { Average } \\
\text { score(total } \\
5)\end{array}$ \\
\hline $\begin{array}{c}\text { Body skin } \\
\text { care }\end{array}$ & $14.8 \%$ & $9.42 \%$ & $21.97 \%$ & $20.63 \%$ & $33.18 \%$ & $3.48 \%$ \\
\hline $\begin{array}{c}\text { Plant Health } \\
\text { Care }\end{array}$ & $13 \%$ & $12.11 \%$ & $23.32 \%$ & $21.97 \%$ & $29.6 \%$ & $3.43 \%$ \\
\hline $\begin{array}{c}\text { Antibacterial } \\
\text { immunity }\end{array}$ & $9.42 \%$ & $6.28 \%$ & $19.28 \%$ & $20.63 \%$ & $44.39 \%$ & $3.84 \%$ \\
\hline $\begin{array}{c}\text { Safety } \\
\text { reflective }\end{array}$ & $17.94 \%$ & $13.45 \%$ & $29.15 \%$ & $17.94 \%$ & $21.52 \%$ & $3.12 \%$ \\
\hline $\begin{array}{c}\text { Intelligent } \\
\text { temperature } \\
\text { control }\end{array}$ & $14.8 \%$ & $10.76 \%$ & $29.6 \%$ & $15.7 \%$ & $29.15 \%$ & $3.34 \%$ \\
\hline Special luster & $16.14 \%$ & $13.45 \%$ & $38.57 \%$ & $17.49 \%$ & $14.35 \%$ & $3 \%$ \\
\hline $\begin{array}{c}\text { Inductive } \\
\text { appearance }\end{array}$ & $17.94 \%$ & $16.14 \%$ & $27.8 \%$ & $18.83 \%$ & $19.28 \%$ & $3.05 \%$ \\
\hline $\begin{array}{c}\text { Environmental } \\
\text { regeneration }\end{array}$ & $8.97 \%$ & $10.76 \%$ & $27.8 \%$ & $26.46 \%$ & $26.01 \%$ & $3.5 \%$ \\
\hline $\begin{array}{c}\text { Radiation } \\
\text { protection }\end{array}$ & $8.52 \%$ & $3.59 \%$ & $23.77 \%$ & $22.87 \%$ & $41.26 \%$ & $3.85 \%$ \\
\hline $\begin{array}{c}\text { High-strength } \\
\text { stretch }\end{array}$ & $10.76 \%$ & $10.31 \%$ & $40.36 \%$ & $18.83 \%$ & $19.73 \%$ & $3.26 \%$ \\
\hline $\begin{array}{c}\text { moisture- } \\
\text { proof }\end{array}$ & $7.17 \%$ & $4.93 \%$ & $20.18 \%$ & $25.56 \%$ & $42.15 \%$ & $3.91 \%$ \\
\hline $\begin{array}{c}\text { Cool touch } \\
\text { Warm } \\
\text { function }\end{array}$ & $7.17 \%$ & $4.04 \%$ & $23.32 \%$ & $27.8 \%$ & $37.67 \%$ & $3.85 \%$ \\
\hline
\end{tabular}




\subsubsection{Analysis on the requirement of environment- friendly fabric}

Environment-friendly fabrics are loved by the majority of employees. The points are mostly between "general" and "very necessary", among which "very necessary" and "necessary" occupied $38.12 \%$ and $24.66 \%$ people who opposed only occupied $10.76 \%$. However, the attitude of enterprises stood in neutral attitude, and this occupied $40.81 \%$. Opponents and supporters accounted for $23.31 \%$ and $35.87 \%$. The adoption of environmentally friendly fabrics mostly depends on the cost of fabrics. The attitude towards environment-friendly fabrics of employees and enterprises are shown as Figure 2 and Figure 3.

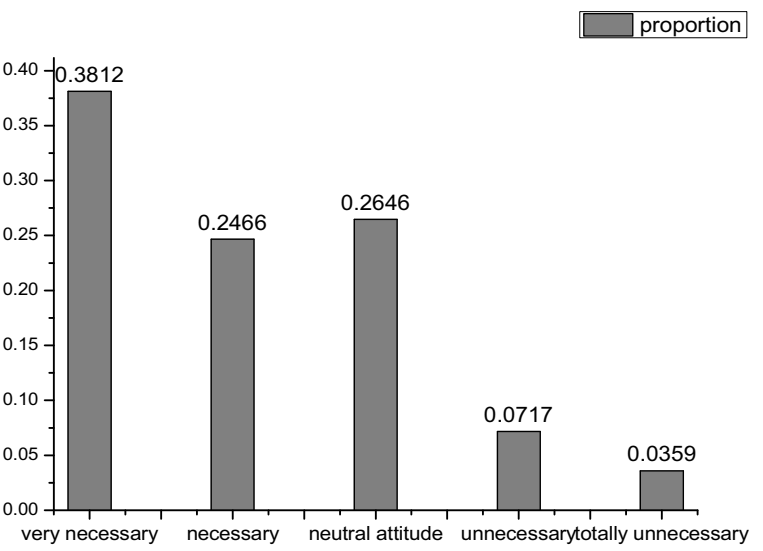

Figure 2. Employees' attitude towards eco-friendly fabrics.

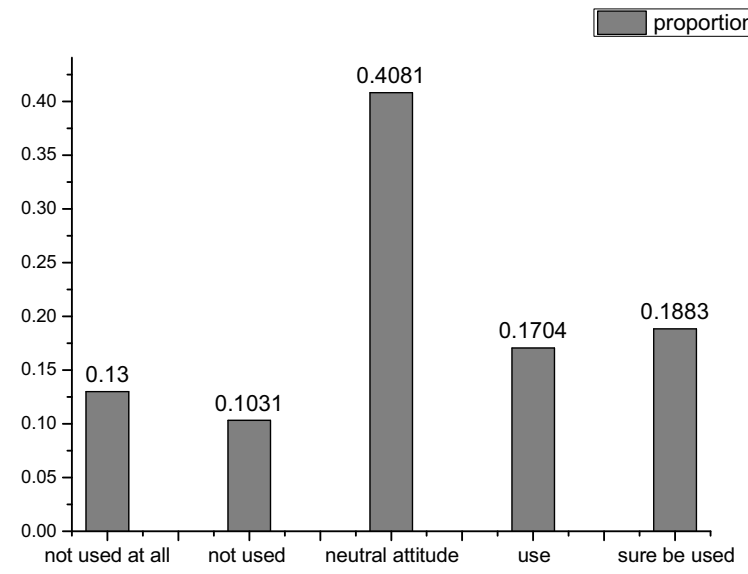

Figure 3. Enterprises' attitude towards eco-friendly fabrics.

\section{Frontier research of shirt functional fabric}

Based on the result of market research, this paper combined the frontier research of some core demands like permeability, anti-wrinkle, anti-penetration, stain resistance, wear resistance, skin-friendly, moisture-proof, radiation protection, antibacterial immunity, cool touch and warm function.

\subsection{Frontier research of shirt basic functional fabric}

The research on the frontier of functional fabrics is expounded from the aspects of Permeability, Antiwrinkle, anti-penetration, Stain resistance; wear resistance and skin comfort. In the frontier research, natural fibers have been studied most extensively. Natural fibers have been used for thousands of years in clothing. However, since the last century, natural fibers have the characteristics of skin-friendly and comfortable, but they are easy to be wrinkled and difficult to take care. In recent years, with the development of fabric technology, the natural fiber began to become thin, soft. Through the sizing, calendaring and other processes to improve the shortcomings of its easy to fold [7]. To be more consistent with the modern fast-paced life, the "fog polymerization" method can improve the wear resistance of cotton fabrics [8]. SLIPS-type fabric is the most prominent research result for Stain resistance, through the SLIPS self-healing coating which has a super smooth feature, to resist the cotton fabric and polyester fabric from any water, ice, oil and bacteria and other substances [9]. Breathable determines the body's contact with the outside world, permeability can help the skin breathe, in addition to the traditional cotton fabric and blended fabrics; the new fabric called "porel" has been loved by its good breathable and quick-drying characteristics [10]. Aiming at the problems of how can the fabric be both thin and opaque, Scientists used the theory of "mie" scattering in the latest research. They innovated a large number of high refractive index powder thin-walled diaphragm, the macro-reflective interface and numerous microscopic reflection interface of the complex fiber, so that the light in any radial incidence will be intercepted, which can improve the anti-penetration effect [11].

Table 5. The Difference of Functional Requirements of Shirt Fabrics

\begin{tabular}{|c|c|c|c|c|c|c|c|c|}
\hline Content & Banking & Government & Education & $\begin{array}{c}\text { Entertain- } \\
\text { ment }\end{array}$ & $\begin{array}{c}\text { Hotel } \\
\text { catering }\end{array}$ & Media & Consultancy & $\begin{array}{c}\text { Shopping } \\
\text { malls }\end{array}$ \\
\hline $\begin{array}{c}\text { Core } \\
\text { Require- } \\
\text { ment }\end{array}$ & $\begin{array}{c}\text { Anti- } \\
\text { wrinkle; } \\
\text { Washable }\end{array}$ & $\begin{array}{c}\text { Anti- } \\
\text { wrinkle; } \\
\text { Washable; } \\
\text { Wear } \\
\text { resistance } \\
\end{array}$ & $\begin{array}{c}\text { Anti- } \\
\text { wrinkle; } \\
\text { Washable; } \\
\text { Stain } \\
\text { resistant } \\
\end{array}$ & $\begin{array}{c}\text { Anti- } \\
\text { wrinkle; } \\
\text { Washable; } \\
\text { Stain } \\
\text { resistant } \\
\end{array}$ & $\begin{array}{l}\text { Stain } \\
\text { resistant }\end{array}$ & $\begin{array}{c}\text { Anti- } \\
\text { wrinkle; } \\
\text { Washable; } \\
\text { Stain } \\
\text { resistant } \\
\end{array}$ & $\begin{array}{c}\text { Anti- } \\
\text { wrinkle; } \\
\text { Washable }\end{array}$ & $\begin{array}{c}\text { Anti- } \\
\text { wrinkle; } \\
\text { Washable }\end{array}$ \\
\hline $\begin{array}{c}\text { Existing } \\
\text { problems }\end{array}$ & $\begin{array}{c}\text { Per- } \\
\text { meability }\end{array}$ & $\begin{array}{c}\text { Per- } \\
\text { meability }\end{array}$ & Permeability & Anti-wrinkle & $\begin{array}{c}\text { Per- } \\
\text { meability }\end{array}$ & $\begin{array}{c}\text { Anti- } \\
\text { wrinkle }\end{array}$ & $\begin{array}{c}\text { Anti- } \\
\text { wrinkle }\end{array}$ & $\begin{array}{c}\text { Per- } \\
\text { meability }\end{array}$ \\
\hline $\begin{array}{c}\text { Core } \\
\text { demands } \\
\text { in } \\
\text { summer }\end{array}$ & $\begin{array}{c}\text { Per- } \\
\text { meability; }\end{array}$ & $\begin{array}{c}\text { Per- } \\
\text { meability; } \\
\text { Stain } \\
\text { resistance }\end{array}$ & $\begin{array}{c}\text { Per- } \\
\text { meability; } \\
\text { Anti- } \\
\text { penetration; } \\
\text { Cool feeling }\end{array}$ & $\begin{array}{c}\text { Per- } \\
\text { meability; } \\
\text { Anti- } \\
\text { perspective; } \\
\text { Cool feeling; }\end{array}$ & $\begin{array}{c}\text { Per- } \\
\text { meability }\end{array}$ & $\begin{array}{c}\text { Per- } \\
\text { meability; } \\
\text { Cool feeling }\end{array}$ & $\begin{array}{c}\text { Per- } \\
\text { meability; } \\
\text { Anti- } \\
\text { perspective }\end{array}$ & $\begin{array}{c}\text { Cool } \\
\text { feeling; } \\
\text { Per- } \\
\text { meability }\end{array}$ \\
\hline
\end{tabular}




\begin{tabular}{|c|c|c|c|c|c|c|c|c|}
\hline $\begin{array}{c}\text { Core } \\
\text { demands } \\
\text { in winter }\end{array}$ & $\begin{array}{l}\text { Skin- } \\
\text { friendly and } \\
\text { comfortable }\end{array}$ & $\begin{array}{c}\text { Skin- } \\
\text { friendly } \\
\text { comfortable }\end{array}$ & $\begin{array}{l}\text { Skin- } \\
\text { friendly and } \\
\text { comfortable }\end{array}$ & $\begin{array}{l}\text { Skin-friendly } \\
\text { and } \\
\text { comfortable }\end{array}$ & $\begin{array}{l}\text { Skin- } \\
\text { friendly } \\
\text { and } \\
\text { comfortable }\end{array}$ & $\begin{array}{l}\text { Anti-static; } \\
\text { Stain } \\
\text { resistant; } \\
\text { Skin- } \\
\text { Friendly } \\
\text { and } \\
\text { comfortable }\end{array}$ & $\begin{array}{l}\text { Skin- } \\
\text { Friendly and } \\
\text { comfortable }\end{array}$ & $\begin{array}{l}\text { Anti-static; } \\
\text { Skin- } \\
\text { friendly } \\
\text { and } \\
\text { comfortable }\end{array}$ \\
\hline $\begin{array}{l}\text { Pre- } \\
\text { ferences } \\
\text { of the } \\
\text { new func- } \\
\text { tional } \\
\text { shirt } \\
\text { fabric }\end{array}$ & $\begin{array}{c}\text { Warm } \\
\text { function; } \\
\text { moisture- } \\
\text { proof; } \\
\text { Radiation } \\
\text { protection; } \\
\text { Environ- } \\
\text { mental } \\
\text { regeneration }\end{array}$ & $\begin{array}{c}\text { Anti- } \\
\text { bacterial } \\
\text { immunity; } \\
\text { Moisture- } \\
\text { proof; } \\
\text { Warm } \\
\text { function; } \\
\text { Cool touch }\end{array}$ & $\begin{array}{c}\text { Radiation } \\
\text { protection; } \\
\text { Moisture- } \\
\text { proof; Anti- } \\
\text { bacterial } \\
\text { immunity; } \\
\text { Anti- } \\
\text { perspective }\end{array}$ & $\begin{array}{l}\text { Moisture- } \\
\text { proof }\end{array}$ & $\begin{array}{l}\text { Moisture- } \\
\text { proof ; } \\
\text { Intelligent } \\
\text { temperature } \\
\text { control }\end{array}$ & $\begin{array}{l}\text { Moisture- } \\
\text { proof; } \\
\text { Radiation } \\
\text { protection; } \\
\text { Cool touch }\end{array}$ & $\begin{array}{l}\text { Moisture- } \\
\text { proof; } \\
\text { Radiation } \\
\text { protection }\end{array}$ & $\begin{array}{l}\text { Moisture- } \\
\text { proof; Cool } \\
\text { touch }\end{array}$ \\
\hline $\begin{array}{c}\text { Fabric } \\
\text { com- } \\
\text { position } \\
\text { pre- } \\
\text { ferences }\end{array}$ & Cotton & Cotton & $\begin{array}{l}\text { Cotton; } \\
\text { Cotton and } \\
\text { chemical } \\
\text { fiber } \\
\text { blended }\end{array}$ & Cotton & Cotton & $\begin{array}{l}\text { Cotton; } \\
\text { Cotton and } \\
\text { linen blend }\end{array}$ & Cotton & Cotton \\
\hline
\end{tabular}

\subsection{Frontier research of shirt new functional fabric}

According to the results of research, the new functional moisture resistance, radiation resistance, antibacterial immunity, cool feeling and warm feeling have a relatively high demand. Through the moisture-proof treatment, the fabric can better prevent the oxidation reaction and hydrolysis reaction, so that the bacterial growth will be reduced. As the frontier research, antimicrobial textile technology can be divided into two categories: the first is to build antibacterial fiber system, and then make various types of antibacterial fabrics. Bamboo fiber has the function of antibacterial. Silver nanoparticles coating on bamboo pulp fabric modified with dopamine is not only antibacterial but also environmentally friendly and easy to carry out [12]. The second is to use antibacterial agents to reach the antibacterial function. For example, using Tragacanth gum/nano silver hydrogel on cotton fabric to In-situ synthesize antibacterial properties [13]. In modern society, electronic products used more frequently, so that electromagnetic radiation and light radiation damage human body seriously; therefore, radiation protection fabrics are being more and more attention. At present, the functional fiber material containing ceramic powder [14] and the silver-silver fiber fabric [15], which fuse nanosilver ions are the main research results in light-proof and electromagnetic radiation. In the study of cool functional fabrics, the new fabric called "Topcool" and "coolmax" is due to its better water absorption and wetting function makes the more comfortable and cooler feeling, the market was well, [16] which have resolved the problem of cotton fiber permeability decreased caused by sweating. The low temperature in winter makes the thin and warm fabric also stand on to opposite side, but the "softwarm" fever fiber, "thermogear" fiber and "eks" fiber can get warm function by absorbing moisture into heat. [17]

\section{Expanding direction of uniform shirt fabric}

\subsection{Environmentally friendly and economical functional shirt fabric}

Nowadays, "sustainable" is a major trends in textile and garment industry. Textile and garment manufacturers are increasingly concerned about sustainable products, which can meet environmental and social requirements at the same time. [18] Since the growing rate of polyester production and lacking of sound recovery system, Recycling of recycled fiber is a small fraction of the total fiber production. The China government made a promise that carbon dioxide emission would decrease by $40 \%$ to $45 \%$ in per unit of GDP in 2020 compared to 2005 [19]. Therefore, recyclable fabrics will become a trend from the national policy. Uniform will be phased out after the bulk procurement, so it will produce a large number of waste fabrics. The recycling problem in uniform industry should be attended and the adoption of recycled fabrics will become a new trend.

In addition to the use of environmentally friendly recycled fiber, some new types of fiber which can reduce carbon dioxide emissions also will become trends. For example, the permanent anti-static environmental fabrics which both have environmental protection and anti-static function, the breathable fabric which both have environmental protection and breathable function [20]. Some fabrics made by plants fibers also can protect the environment and improve the wearing comfort.

According to the survey of this paper, enterprises stand in neutral attitude most in the use of environmentally friendly fabrics, and the main factor is fabric costs. Uniform shirts cost can be accepted in the range of 200-400 yuan to the most proportion. Therefore, how to create economic functional fabric, which can both satisfy the basic needs and environmental protective 
function is the develop direction for uniform shirt in the future.

\subsection{Exclusive functional fabrics based on the differences among industries}

Due to the differences of working environment, there are some differences on industries' needs. The main difference is about the new function requirements. In terms of the basic function needs, most industries seemed to be similarity. Fabric functional design can be based on industry characteristics to construct industry exclusive shirt fabric. For example, for the long-term using of electronic equipment crowd such as banking and financial industry, fabrics can be added radiation protection and health care functions like blood circulation promotion; outdoor working industries such as logistics and transportation can be added UV protection in the fabric; for some students especially the teenagers, shirt fabric can be added anti-bacterial immune function. Function design of the uniform shirt fabric should according to the characteristics of the industry, and base on the economic, environmental protection, security and other multi-angle sides.

Reference on the Maslow's hierarchy of needs theory, functional uniform shirt fabric design can rely on a fourlevel mining process (Figure 4). The first layer of fabric functional demands on the basic functional needs, such as permeability, wrinkle resistance, skin-friendly. The second layer pays attention to human safety, such as radiation protection, anti-ultraviolet function, and security alerts function; The third layer focuses on personal care, such as plant health care and warm function; the forth layer can stand for the social value of enterprises, such as environmental protective function. Exclusive functional fabrics can be based on enterprise needs and economic strength or its social value. Functional requirements are gradually optimized from the grass-roots level to the top level.

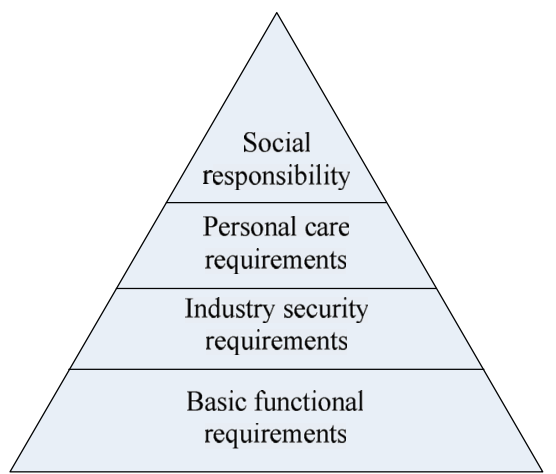

Figure 4. Design levels of exclusive functional shirt fabrics.

\section{Conclusions}

The value of functional fabrics used in uniform industry can be expressed in social value, management value, economic value and cultural value, and its significance cannot be underestimated. Anti-penetration, anti-wrinkle and other basic functions are the most prominent functions. New functional shirt fabrics have differences between industries. Environmentally friendly fabrics have a certain degree of recognition, but because of the cost, enterprises take a neutral attitude. Therefore, the uniform shirt fabric function design can be combined in economic side and environmental friendly side. Environmentally friendly and economical functional shirt fabrics need to be developing in the future. Material designer can abbey four levels to design according to the needs of enterprise, those are: basic functional requirements, industry security requirements, personal care requirements, social responsibility.

\section{Acknowledgments}

The authors would like to appreciate the fund projects below:

1. Shanghai Fashion Design \& Value Creation Collaborative Innovation Center. (ZX201311000031)

2. Chinese Central Communist special funds for basic research projects in Donghua University (NO. 16D110715), which focusing on the research and application of Fashion trend from uniform perspective.

\section{References}

1. See Blair, M. M. (1998). For whom should corporations be run? An economic rationale for stakeholder management. Long Range Planning, 32(2), 195-200.

2. Thorpe, J. (2003).Developing value: The business case for sustainability in emerging markets. Greener Management International, 44:17- 32.

3. MAI Sheng, WANG Keyi, KUANG Haibo. (2011).A Study on the evaluation of enterprise social value. Science Research Management, 6, 11.

4. WANG Xiaoxi. (2011). Economic Value of Morality].Social Sciences in China, 4, 55-66.

5. BAO Lifeng.(2011). The value of people oriented corporate culture environment and construction. Northeast Normal University.

6. FENG Qiaosi, FENG Yuan. (2013). Construction of corporate culture and environmental management value system. Accounting research, 8, 24-31.

7. ZHU Yuansheng. (2002). New development of natural fiber fabrics. Journal of Ningbo Vocational and Technical College, 1, 10-12.

8. FAN Wanchao. (2016). Study on "Fog Polymerization" Method for Strengthening Wear Resistance of Textile Fabrics. Zhejiang University of Science and Technology.

9. MENG Xianguo. (2014, May 3). SLIPS-type super anti-fouling fabric research has been successful developed. China Textile News.

10. YI De. (2013). Porel,a breathable quick-drying fabric. Textile Decoration Technology, 4, 23.

11. WEN Weijian. (2013, April 9) you will never worry about "emptied"when you wear light-colored clothes.

12. PENG Linghui; Guo Ronghui; Lan Jianwu. (2016). Microwave-assisted deposition of silver nanoparticles on bamboo pulp fabric through 
dopamine functionalization. Applied surface Science, 386,151-159.

13. Montazer, M.; Keshvari, A.; Kahali, P. (2016).Tragacanth gum/nano silver hydrogel on cotton fabric: In-situ synthesis and antibacterial properties. Carbohydrate polymers, 154, 257-26.

14. Qi Lu. (1999). Research on ceramic powder of PP fiber material, 4,152-154.

15. SONG Kexin. LIU Lianjun. SUN Guodong. (2011). Production of bamboo silver antimicrobial radiation fabrics. Cotton Textile Technology, 8, 53-56.

16. LIU Peng, LIU Yanjun, FENG Lanqing. (2012). Application of wicking fiber in knitting, 2, 59-60.
17. LI Ling, MENG Jiaguang. (2010). Application of wicking fiber in knitting. The Sixteenth National Fancy Yarn and its textile technology progress seminar Proceedings, CA.

18. CHE Yinghong. (2015). New environmentally friendly textiles. Printing and dyeing, 22, 56-57.

19. SHAO Wei. (2015). High-performance fibers and green fibers to play the important task of the industry, Textile and Apparel Weekly, 42, 34-35.

20. LIANG Liping. (2011 October 6) Focus on low carbon environmental protection - Nanshan new functional fabric. China Textile News, 1. 